\title{
Inhibitory Effect of Lantana camara L., Eclipta prostrata (L.) L. and Cosmos caudatus Kunth. Leaf Extracts on ADP-Induced Platelet Aggregation
}

\author{
Ni Made Dwi Sandhiutami*, Yesi Desmiaty, Noviyanti
}

\section{Ni Made Dwi Sandhiutami*, Yesi Desmiaty, Noviyanti}

Faculty of Pharmacy, University of Pancasila, Jakarta, INDONESIA

Correspondence

Ni Made Dwi Sandhiutami

Faculty of Pharmacy, University of Pancasila, Jakarta, INDONESIA

+62217864727

E-mail: dwi_sandhiutami@yahoo.com

\section{History}

- Submission Date: 12-01-2018;

- Review completed: 14-02-2018;

- Accepted Date: 14-02-2018

DOI : 10.5530/pj.2018.3.95

Article Available online

http://www.phcogj.com/v10/i3

\section{Copyright}

(C) 2018 Phcog.Net. This is an openaccess article distributed under the terms of the Creative Commons Attribution 4.0 International license.

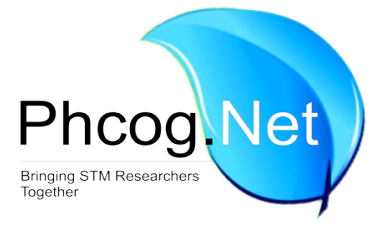

\begin{abstract}
Objective: The leaves of Lantana camara L., Eclipta prostrata (L.) L. and Cosmos caudatus Kunth. are rich in flavonoids, saponins and essential oils. This study was carried out to determine the antiplatelet effect of the three plant extracts on ADP-induced platelet aggregation. Methods: The samples consisted of clopidogrel as positive control, aquadest as negative control and test extracts with concentrations of $40,60,80$ and $100 \mathrm{mg} / \mathrm{ml}$. Platelet Rich Plasma (PRP) was added for each extract concentration. The absorbance test of the samples was measured at $600 \mathrm{~nm}$, before and after the addition of $20 \mu \mathrm{L}$ adenosine diphosphate (ADP) $5 \mathrm{mM}$. After ADP added, then measured again the plasma absorbance was measured of the same wavelength. Antiplatelet aggregation activity was determined by calculating plasma absorbance before and after addition of ADP. Results: The results showed that the inhibitory percentage of platelet aggregation with extract concentrations of $100,80,60$ and $40 \mathrm{mg} / \mathrm{ml}$ were Lantana camara L. leaf extract $(91.17 \% ; 73.27 \% ; 72.86 \%$ and $37.15 \%)$, Eclipta prostrata (L.) L. leaf extract $(74.55 \% ; 65.60 \% ; 48.00 \%$ dan $39.08 \%)$ and Cosmos caudatus Kunth. Leaf extract $(59.17 \%$; $52.56 \% ; 14.25 \%$ dan $13.82 \%)$, respectively. The test extracts inhibited in vitro ADP-induced platelet aggregation with $\mathrm{IC}_{50}$ value were as follows: $47.09 \mathrm{mg} / \mathrm{ml}$ (Lantana camara L), 59.02 $\mathrm{mg} / \mathrm{ml}$ (Eclipta prostrata (L.) ${ }^{5}$.) and $87.26 \mathrm{mg} / \mathrm{ml}$ (Cosmos caudatus Kunth.) Conclusion: The present work demonstrated that the three extracts could inhibit in-vitro ADP-induced platelet aggregation and the best potency was shown by Lantana camara $\mathrm{L}$ leaf extract.
\end{abstract}

Key words: Anti-platelet aggregation, Cosmos caudatus kunth., Eclipta prostrata (L.) L., Lantana camara L.

\section{INTRODUCTION}

Stroke is commonly caused by cardiovascular disorders such as atherosclerosis. Atherosclerosis is not a degenerative process, but it is a chronic inflammatory process followed by a process of reparation in the artery wall. ${ }^{1}$ The journey of atherosclerosis is histopathologically divided into several stages: 1) early lesions (fatty streak, with microthrombi), 2) lesions up (fibrosis, plaques of atheroma-atherosclerotic) and 3) the complicated lesions (ulceration, calcification, hemorrhage, gangrene, aneurysm and infarction). The complicated lesions occur on the process of thrombosis, platelet adhesion, platelet aggregation, and coagulation due to atheroma plaque rupture in arteries. Inside the plaque the process of coagulation occurs due to mixed blood with collagen. Coagulation factors such as factor VII activates factor $\mathrm{X}$ to occur, catalyze the conversion of prothrombin into thrombin to stabilize thrombus which then secrete platelet deposition and platelet derived growth factor (PDGF). Thrombus can undergo dissolution (lost) so that patients do not experience symptoms. Thrombus can also be attached to the process of atherosclerosis in which the blockage inside the artery lumen grows larger and cause clinical symptoms. Rupture or rupture of plaque followed by thrombus formation results in sudden lumen occlusion. Formed thrombus can cause a range of clinical symptoms because the thrombus goes along with the bloodstream and clog blood vessels distal to the size will be smaller. If the rupture is very large, then most likely there will be a blockage in the large blood vessels. ${ }^{1}$ The formation of such thrombus is medically preventable with antiplatelet aggregation agents.

Some of medicinal plants from Indonesia have hemostasis-related activities e.g Lantana camara L., Eclipta prostrata (L.) L.) dan Cosmos caudatus Kunth). Based on phytochemical screening, ethanol extract from the leaves of Lantana camara L. contains flavonoid, saponin, and essential oil, whilst the Cosmos caudatus Kunth. Leaves contained alkaloid, flavonoid, saponin, steroid, phenolic, and terpenoid., ${ }^{2,3}$ Phytochemical screening of Eclipta prostrata (L.) L.
Cite this article: Sandhiutami NMD, Desmiaty Y, Inhibitory Effect of Lantana camara L., Eclipta prostrata (L.) L. and Cosmos caudatus Kunth. Leaf Extracts on ADP-Induced Platelet Aggregation. Pharmacog J. 2018;10(3):581-5. 
ethanolic extract leaves showed the presence of flavonoid, quinone, tannin, steroid and triterpenoid. ${ }^{4}$ Previous research on other plants revealed the plants containing flavonoid, saponin and essential oil had platelet aggregation activity.

According to Middleton et al (2000), flavonoid compound can inhibit platelet aggregation by blocking the synthesis of arachidonic acid by cyclooxygenase which results the inhibition of thromboxane A2 leading to inhibition of platelet aggregation. ${ }^{5}$ Grice et al (2010) proved that the content of essential oils like eugenol and elemycin had antiplatelet activity as they can inhibit adenosine diphosphate (ADP) induction during platelet aggregation process. ${ }^{6}$ Meanwhile, Lee et al (2005) demonstrated that antiplatelet activity of saponin can inhibit the action of calcium ion as during platelet aggregation process calcium ion can promote vasoconstriction. ${ }^{7}$ On the grounds of the aforementioned findings, the presence of the three compounds may inhibit the formation of platelet aggregation. One of studies on Eclipta prostrata (L.) L., was to evaluate the anti-inflammatory using carragenin to generate strong anti-inflammatory effect on rats. ${ }^{8}$ The research on Lantana camara L. and Cosmos caudatus Kunth. as platelet antiaggregation agents has not been found yet. However, a study revealed that Lantana camara and Cosmos caudatus had anti-inflammatory activity. ${ }^{2,9}$ and the result from this study can be explored further to investigate their platelet anti-aggregation activities as the inflammatory process is associated with the formation of thrombus in the blood vessel.

\section{MATERIALS AND METHODS}

It was an experimental study to examine the potential of antiplatelet aggregation in reducing plasma absorbance from ethanol $70 \%$ extracts from the leaves of Lantana camara L., Eclipta prostrata (L.) L. and Cosmos caudatus Kunth. Consequently, it may prove the potential activity of the extracts to inhibit platelet aggregation.

\section{Materials}

Dry leaf of Lantana camara L., Eclipta prostrata (L.) L. and Cosmos caudatus Kunth. (obtained from Balittro, Bogor), ethanol, Adenosin Diphosphate (ADP) (Sigma-Aldrich), Platelet Rich Plasma (PRP) (Indonesian Red Cross, DKI Jakarta), clopidogrel (Kimia Farma), $\mathrm{NaCl}$ 0,9\% (Otsuka), amyl alcohol, chloroform, ammonia, anhydrous acetic acid, sulfuric acid, $\mathrm{NaOH}$, ferric (III) chloride, gelatine, Steasny reagent, Sodium acetate, Dragendroff reagent, Mayer reagent, petroleum ether, and aquadest.

Testing was initiated by determination of the plants by Herbarium Bogoriense, Botany Department of Biology Research Centre (LIPI), Bogor. Extraction was done by maseration method with $70 \%$ ethanol to obtain concentrated extract followed by phytochemical screening.

There were three treatments of the test group: positive control, negative control and extracts from each test plant. The extracts were made into a series of concentrations $(40 ; 60 ; 80$; and $100 \mathrm{mg} / \mathrm{ml})$. Each $2.5 \mathrm{~g}$ of extracts was weighed and then dissolved into $25 \mathrm{ml}$ of aquadest and homogenized to obtain $100 \mathrm{mg} / \mathrm{ml}$ concentration. Dilution of the concentration of $100 \mathrm{mg} / \mathrm{ml}$ was carried out into $10 \mathrm{ml}$ of aquadest to obtain concentration $80 \mathrm{mg} / \mathrm{ml}$, then diluted again to get $60 \mathrm{mg} / \mathrm{ml}$ concentration, and diluted again to get concentration $40 \mathrm{mg} / \mathrm{ml}$.

Samples of test extracts (40;60; 80 and $100 \mathrm{mg} / \mathrm{ml})$, clopidogrel $2 \mathrm{mg} / \mathrm{ml}$ (positive control) and aquadest (negative control) were pipetted with $100 \mu \mathrm{L}$, then added to $450 \mu \mathrm{L}$ platelet preparation (PRP) on a closed tube. Each tube was homogenized with vortex for $\pm 3 \mathrm{~min}$. The procedures were replicated 3 times for each sample. The absorbance test of the sample was measured at $600 \mathrm{~nm}$ using Spektrophotometer visible (UV Mini 124 Shimadzu). Before measuring the absorbance, $20 \mu \mathrm{L}$ of ADP $5 \mathrm{mM}$ was added to each sample. Then, the samples were incubated for $\pm 20 \mathrm{~min}$, then plasma absorbance of the samples were measured again using the same wavelength. ${ }^{10}$ Finally, percent inhibitory percentage for each extract was calculated according to the following formula:

Percentage of platelet aggregation was calculated using the following formula (10):

$$
\% \text { Platelet aggregation }=\frac{1-\mathrm{B}}{\mathrm{A}} \times 100 \%
$$

Denote: $\quad \mathrm{B}=$ absorbance after ADP addition

$\mathrm{A}=$ absorbance before ADP addition

(\% Aggregation of negative control -

$\%$ inhibitory of platelet aggregation $=\frac{\% \text { platelet aggregation })}{(\% \text { Aggregation of negative control })} \times 100$

The anti-agregation activity of each extract was expressed as $\mathrm{IC}_{50}$ values (the concentration of the compound causing 50\% inhibitory effects). The $\mathrm{IC}_{50}$ values were estimated by non linear curve-fitting and presented as their respective $95 \%$ confidence limits. One-way analysis of variance (ANOVA) followed by Tukey's post test was used to assess the significant differences $(p<0.05)$ between the responses caused by the extracts. All the statistical analyses were accomplished using the computer software GraphPad Prism 3.02 for Windows (GraphPad Software, USA).

\section{RESULTS AND DISCUSSION}

It can be seen in Table 1 that the phytochemical screening indicated the presence of secondary metabolite compounds contained in $70 \%$ ethanol extracts from the leaves of Lantana camara L., Eclipta prostrata (L.) L. and Cosmos caudatus Kunth. The secondary metabolite compounds included flavonoid, saponin, essential oil, tannin and steroid. The compounds were believed to have activity as anti-platelet aggregation.

Based on data shown in Figure 1 and 2 , testing of Lantana camara extract with concentration of $100 \mathrm{mg} / \mathrm{ml}$ resulted in the lowest aggregation percentage of $2.83 \% \pm 2.16$ with a percentage of the highest aggregation inhibition of $91.17 \%$. The highest percentage of platelet aggregation was shown by concentration of $40 \mathrm{mg} / \mathrm{ml}$ equal to $20.15 \% \pm 2.77$ giving inhibition with value $37.15 \%$. Compared with the measurement data of Eclipta prostrata leaf extract at concentration of $100 \mathrm{mg} / \mathrm{ml}$ resulted in the lowest percent aggregation of $8.16 \% \pm 0.57$ with the highest inhibition percentage of $74.55 \%$, whereas at concentration of $40 \mathrm{mg} / \mathrm{ml}$ yielded the highest percentage of platelet aggregation of $19.53 \% \pm 0.57$ which gave an inhibitory value of $39.08 \%$. Meanwhile, measurement of Cosmos caudatus leaf extract at concentration of $100 \mathrm{mg} / \mathrm{ml}$ gave the biggest percentage of inhibition ( i.e 59.17\%) of all concentrations (80, 60 and $40 \mathrm{mg} / \mathrm{ml}$ ) with aggregation percentage $13.09 \% \pm 0.74$, while concentration of $40 \mathrm{mg} / \mathrm{ml}$ had platelet aggregation percentage of $27.63 \% \pm 0.57$ which resulted in $13.82 \%$ of inhibition percentage.

Based on observations and measurement data on platelet aggregation, the higher concentration of extracts resulted in smaller resulting aggregation value so that the lower concentration of extract used may yield the greater ability of platelets to aggregate. While the capability of platelet aggregation inhibition in this study showed that the higher concentration of extract used, yielded greater inhibitory value and the lower concentration of inhibition resulted in smaller aggregation. This difference can be seen in Figure I. and Figure II.

Platelet or thrombosis is one of type of blood cells. Platelets have a small size, i.e. one-third of the size of red blood cells. Each millimeter cubic of the blood contains 300.000 platelets and life span are only 8-10 days old. Platelets are derived from megakaryocytes located in the bone marrow and have no nuclei. Platelets play an important role in the blood clotting 
Table 1: Phytochemical Screening of Ethanolic Leaf Extracts from Lantana camara L., Eclipta prostrata (L.) L. and Cosmos caudatus Kunth.

\begin{tabular}{cccc}
\hline & & Results of Extract Screening \\
\cline { 2 - 4 } Group of Compounds & Lantana camara L. leaf & Eclipta prostrata (L.) L. leaf & Cosmos caudatus Kunth. leaf \\
\hline Alkaloid & - & + & + \\
Flavonoid & + & + & + \\
Saponin & + & + & + \\
Essential Oil & + & - & + \\
Tannin & + & $+/+$ & + \\
Quinone & - & + & - \\
Steroid/ triterpenoid & $+/-$ & - & + \\
Coumarin & - & +
\end{tabular}

Table 2: Effect of ethanolic extract of Lantana camara L., Eclipta prostrata (L.) L.) and Cosmos caudatus Kunth). leaves on in-vitro ADP- induced platelet aggregation.

\begin{tabular}{cc}
\hline Samples & $\mathrm{IC}_{50}(\mathrm{mg} / \mathrm{ml})$ \\
\hline Lantana camara L. & 47.09 \\
Eclipta prostrata (L.) L. & 59.02 \\
Cosmos caudatus Kunth. & 87.26 \\
Positive control (Clopidogrel) & 1.12 \\
\hline
\end{tabular}

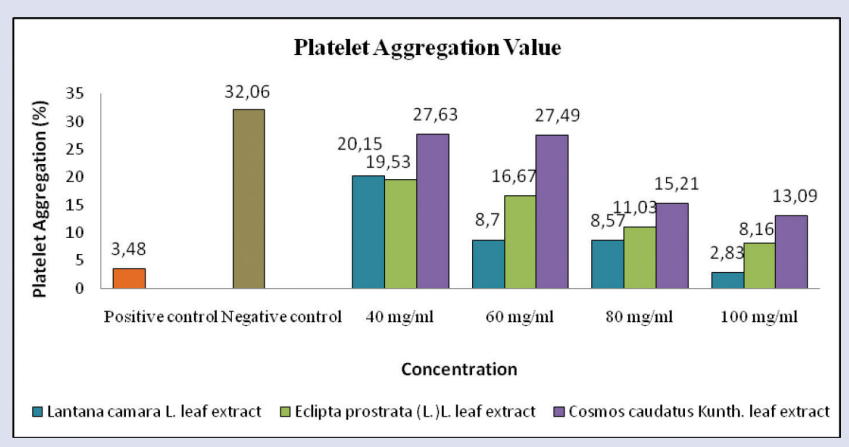

Figure 1: Percentage of platelet aggregation of each extract.

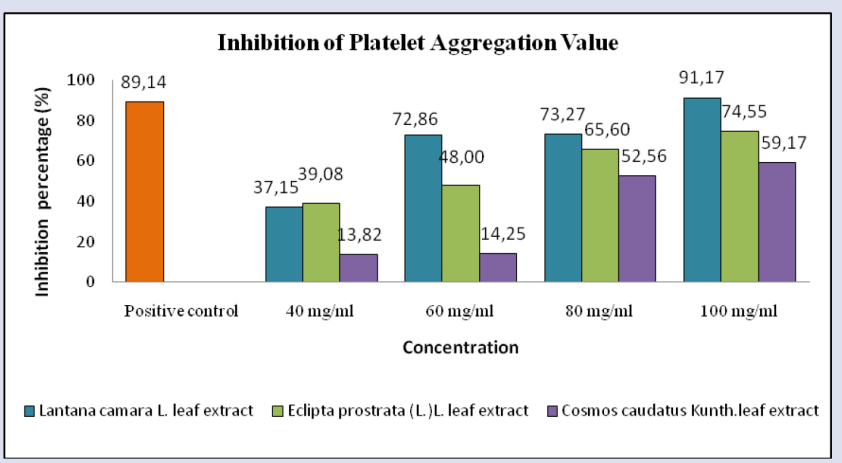

Figure 2: Inhibitory percentage of platelet aggregation of each extract. process and maintain the integrity of the systemic circulation. Under normal circumstances the shape is like a disc, but when activated it will be rounded then elongated and tapered irregular. In healthy conditions, the vascular endothelium prevents platelet adhesion. ${ }^{11,12}$

Platelets have been known to play a role in the pathogenesis of atherosclerotic complications and thrombus formation. Thrombus is composed of platelets, erythrocytes, and a small proportion of leukocytes trapped in fibrin webbing. The platelets aggregate with each other and will stimulate the release of more A2 thromboxane, which further stimulates other platelets for further aggregation. The formation of thrombus in the blood vessels and the heart will block blood flow in the brain resulting in further damage to the brain leading to stroke. ${ }^{13}$

The binding platelet to the cell endothelium will occur in blood vessel walls undergoing injury through bonding with GP receptors. Platelet will be active through an intracellular signaling process and cause the production and release of agonists such as TXA2 and ADP, and thrombin. These factors will bind to GPCR receptors ( $G$ protein-coupled receptors), and mediate the activation of paracrine and autocrine platelets. This process will potentiate other actions (P2Y12 signaling modulate thrombin generation). In the end, the GPIIb/IIIa integrin will mediate platelet activation in the presence of platelet form changes, the formation of fibrinogenic bonds, and vWF which will lead to platelet aggregation. ${ }^{14}$

Platelet aggregation is the ability of platelets to stick together with each other in the form of a plug. In this study platelet aggregation was triggered by the addition of ADP agonists. Induction using ADP causes platelets to be activated. The binding of ADP to the platelet membrane may activate the phospholipase enzyme, hydrolyzing phospholipids to produce arachidonic acid. Arachidonic acid is converted by cyclooxygenase enzymes to prostaglandin $\mathrm{H} 2$ ( $\mathrm{PGH} 2$ ) form, which is then converted to thromboxane A2 by thromboxane synthase. Thromboxane A2 is an inducer of platelet aggregation. ${ }^{15}$

Adenosine diphosphate (ADP) is the most important platelet agonist that plays a role in hemostasis and thrombosis pathophysiologic arterial. $\mathrm{ADP}$ is a platelet agonist that will cause platelet form changes, granular release, and aggregation formation. This occurs with the help of other platelet agonists ie thromboxane A2. The effect of ADP is mediated by the presence of $\mathrm{P} 2 \mathrm{Y} 1, \mathrm{P} 2 \mathrm{Y} 12$ and $\mathrm{P} 2 \mathrm{X} 1$ receptors. ${ }^{16}$ Platelet response to ADP requires the activation of two GPCR (G protein-coupled receptors) receptors, P2Y1 and P2Y12. Drugs such as tiklopidin and klopidogrel will block the activation of P2Y12. CD39 located on the surface of endothelial cells, hydrolyzes ADP into an inactive AMP, PGI2 and NO, which also increases the concentration of cAMP and cGMP in platelets. ${ }^{17}$ 
In this study, clopidogrel $75 \mathrm{mg}$ with concentration of $2 \mathrm{mg} / \mathrm{ml}$ is used as a positive control at a dose of $75 \mathrm{mg}$. Clopidogrel is a drug that is very similar to ticlopidine which works by inhibiting platelet aggregation induced by ADP. This drug appears to be more rare cause thrombocytopenia and leukopenia than ticlopidine. The dose is generally $75 \mathrm{mg}$ / day with or without a loading dose of $300 \mathrm{mg} \cdot{ }^{18}$ Clopidogrel is a safer drug that has been widely replaced by ticlopidin. Most of the previous clinical studies have examined clopidogrel in combination with aspirin. As in the study Antiplatelet Effects of Clopidogrel Compared with Aspirin after Myocardial Infarction: Enhanced Inhibitory Effects of Combination Therapy conclude that in a prospective clinical study of platelets ex vivo, clopidogrel was more effective than aspirin in inhibiting aggregation and ADP-induced platelet activation. Clopidogrel in combination with aspirin showed a synergistic inhibitory effect after stimulating collagen and thrombin with monotherapy. ${ }^{19}$

In this study, inhibition of platelet aggregation in vitro showed the presence of anti-platelet aggregation activity of the three types of extracts. These activities are believed due to the presence of flavonoid, saponin, essential oil, tannin and steroid. Antiplatelet aggregation activity of flavonoid blocks the formation of arachidonic acid metabolism by cyclooxygenase (5). In the platelet, cyclooxygenase product is mainly thromboxane A2 which inhibits the adenylate cyclase enzyme which causes a change in ATP into cAMP, so that lower cAMP levels. CAMP serves to control the concentration of free calcium ions in platelets that cause adhesion and aggregation. Low levels of cAMP would lead to the concentration of free calcium ions into high and result in the adhesion and aggregation of platelets. ${ }^{20}$ While the content of essential oils such as eugenol or elemicin can inhibit ADP-induced platelet aggregation. Eugenol also tend to have potential in the treatment of other diseases associated with platelet aggregation, such as thrombosis, transient ischemic, inflammatory, tumor growth and increased atherosclerosis, ${ }^{6}$ and the antiplatelet action of saponins can inhibit the action of calcium ions because calcium ions work as a promoter vasoconstriction in blood vessel.? The platelet aggregation inhibitory assay is performed by calculating the percent aggregation of plasma absorbance before and after addition of ADP. Aggregation value of negative control is greater than that in the group of test extract and positive control. The result occurs due to the absence of cyclooxygenase enzyme that inhibits platelet aggregation. Meanwhile, the platelet aggregation value of the positive control (with the addition of clopidogrel) is smaller. Similarly, in the test group of ethanol extracts from the leaves of tembelekan, uring aring and kenikir, aggregation value is higher along with the smaller of extract concentration. The anti-platelet aggregation test describes the increase or decrease in absorbance produced after the addition of ADP. ADP is a major inducer for platelet aggregation, platelet change, and platelet secretion. ADP and other platelet activation factors are released by endothelial cells in the wounded area during the vascular phase. ADP causes platelet aggregation by binding to protein receptors present in platelet membranes. The activated platelets release granular which will increase aggregation with other platelets. ${ }^{21}$

The evident of platelet activity can be seen from changes in plasma absorbance measured at a $600 \mathrm{~nm}$ wavelength. Initial plasma absorbance shows plasma turbidity which containing platelet that not yet aggregated. After addition of ADP, the plasma absorbance will decrease because platelets in plasma begin to form aggregate and then settle so that plasma turbidity is reduced. ${ }^{21}$

\section{CONCLUSION}

From this research, it can be concluded that the ethanol $70 \%$ extract from leaves of Lantana camara L., Eclipta prostrata (L.) L. and Cosmos caudatus Kunth. have potential as platelet aggregation inhibitory. Increased concen- trations of each plant extract showed an increased potencial as an inhibitor of platelet aggregation. Of all test extracts, Lantana camara L. leaf extract has the best potency for inhibiting platelet aggregation.

\section{ACKNOWLEDGEMENT}

We thank to Faculty of Pharmacy, University of Pancasila for funding and supported this research by "Hibah Insentif Faculty of Pharmacy, University of Pancasila"

\section{ABBREVIATIONS USED}

ADP: Adenosine Diphospate; PRP: Platelet Rich Plasma; PDGF: Platelet Derived Growth Factor; IC50: Inhibition Concentration 50; ANOVA: One-way Analysis of Variance; TXA2: Thromboxan A2; GPCR: G Protein-Couple Receptor; PGH2: Prostaglandine H2.

\section{CONFLICT OF INTEREST}

The authors declare no conflcit of interest.

\section{SUMMARY}

The ethanol 70\% extract from leaves of Lantana camara L., Eclipta prostrata (L.) L. and Cosmos caudatus Kunth. have potential as platelet aggregation inhibitory. Increased concentrations of each plant extract showed an increased potencial as an inhibitor of platelet aggregation. Of all test extracts, Lantana camara L. leaf extract has the best potency for inhibiting platelet aggregation.

\section{REFERENCES}

1. Rahman A. Faktor-faktor Risiko Mayor Aterosklerosis Pada Berbagai Penyakit Aterosklerosis di RSUP DR. Kariadi Semarang. Semarang: Fakultas Kedokteran Universitas Diponegoro. 2012

2. Hidayati NA. Kandungan Kimia dan Uji Anti inflamasi Ekstrak Etanol Lantana camara L. pada Tikus Putih (Rattus norvegicus) Jantan. Bioteknologi. 2008;5(1):10-7.

3. Rahman AF. Uji Sitotoksisitas Ekstrak Daun Kenikir (Cosmos caudatus) Terhadap Sel Fibroblas BHK-21 (skripsi). Surabaya: Fakultas Kedokteran Gigi Universitas Airlangga. 2013

4. Sukandar EY, dkk. Aktivitas ekstrak etanol herba seledri (Apium graveolens) dan daun urang aring (Eclipta prostata (L.) L.) terhadap Pityrosporum ovale. Majalah Farmasi Indonesia. 2006:17(1):7-12.

5. Middleton E, Kandaswami C, dan Theoharides TC. The Effects of Plant Flavonoids on Mammalian Cells: Implications for Inflammation, Heart Disease, and Cancer. The American Society for Pharmacology and Experimental Therapeutics. 2000;52(4):673-751.

6. Grice D, Rogers KL, dan Griffiths LR. Isolation of Bioactive Compounds That Relate to the Anti-Platelet Activity of Cymbopogon ambiguus. Evidence-Based Complementary and Alternative Medicine. 2010;10:1-8.

7. Ratnaning S. Uji Aktivitas Antiplatelet dan Trombolitik Ekstrak Etanol Kulit Buah Jeruk Purut (Citrus hysrix D. C.) In vitro (skripsi). Jember: Fakultas Farmasi Universitas Jember. 2015

8. Sureshkumar S, dkk. Evaluation of Anti-Inflammatory Activity of Eclipta Alba In Rats. Ancient Science of Life. 2005;24(3):112-8.

9. Ajaykumar TV, dkk. Anti-Inflamatory Activity of Cosmos Caudatus. International Journal of Universal Pharmacy and Bio Sciences: Malaysia. 2012;1(2):2319-8141.

10. Rahardhini A. Uji Aktivitas In vitro Antiplatelet dan Antikoagulan Fraksi N-Heksana Kulit Batang Belimbing Wuluh (Averrhoa bilimbi L.). Skripsi. Jember: Fakultas Farmasi Universitas Jember. 2015

11. Pearce Evelyn. Anatomi dan Fisiologi Untuk Paramedis. Jakarta: PT. Gramedia Pustaka Utama. 2009

12. Nugroho AE. Farmakologi: Obat-obat Penting dalam Pembelajaran Ilmu Farmasi dan Dunia Kesehatan. Yogyakarta: Pustaka Pelajar. 2012

13. Vandy I. Role of Mean Platelet Volume in Thrombotic Stroke. J Majority. 2015;4(2): 129-32

14. Angiolillo DJ, Capodanno D, dan Goto S. Platelet Thrombin Receptor Antagonism and Atherothrombosis. European Heart Jurnal. 2010;31(1):17-28.

15. Erfani IA, dkk. Uji Aktivitas Antiplatelet Fraksi N-Heksana, Kloroform, dan Etanol Daun Belimbing Wuluh (Averrhoa bilimbi L.) In vitro. Prosiding Seminar Nasional Current Challenges in Drug Use and Development, Tantangan Terkini Perkembangan Obat dan Aplikasi Klinis. 2016 
16. Jin, J. Adenosine diphosphate (ADP)-induced Thromboxane A2 Generation in Human Platelets Requires Coordinated Signaling Through Integrin Alpha II Beta 3 and ADP Receptors. Blood. 2002;99(1):193-8.

17. Woulfe D, Yang J, dan Brass L. ADP and Platelet: The End of The Beginning. Journal of Clinical Investigatio. 2001;107(12):1503-5.

18. Setiabudy R, dkk. Farmakologi dan Terapi. Edisi 5. Jakarta: Departemen Farmakologi dan Terapeutik Fakultas Kedokteran Universitas Indonesia. 2007. Hal. 231-232, 814.

19. Moshfegh, Khatereh, dkk. Antiplatelet Effects of Clopidogrel Compared with Aspirin After Myocardial Infarction: Enhanced Inhibitory Effects of Combination
Therapy. Journal of the American College of Cardiology. 2000;36(3):699-705.

20. Astuti P. Peranan Asetosal Sebagai Antitrombotik Terhadap Metabolisme Tromboksan A2 (TXA2) dan Prostasiklin (PGI2). Stomatognatic (J.K.G. Unej). 2010;7(1):51-5.

21. Shalehah A, dkk. Pengaruh Pemberian Ekstrak Etanol Daun Kajajahi (Leucosyke capitellata Wedd.) Terhadap Efek Pembekuan Darah Dan Penurunan Agregasi Platelet Pada Darah Manusia Sehat Secara In vitro. Pharmacy. 2015;12(2):140-52.

\section{GRAPHICAL ABSTRACT}

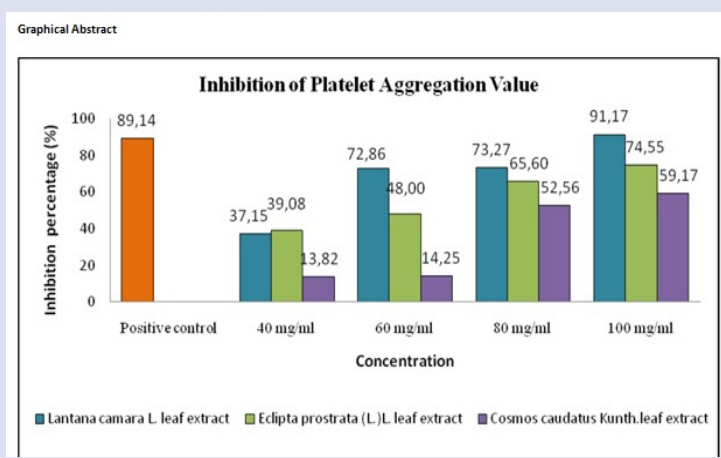

\section{SUMMARY}

The ethanol 70\% extract from leaves of Lantana camara L., Eclipta prostrata (L.) L. and Cosmos caudatus Kunth. have potential as platelet aggregation inhibitory. Increased concen $\neg$ trations of each plant extract showed an increased potencial as an inhibitor of platelet aggregation. Of all test extracts, Lantana camara L. leaf extract has the best potency for inhibiting platelet aggregation.

\section{ABOUT AUTHORS}

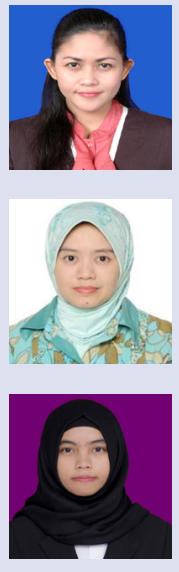

Ni Made Dwi Sandhiutami: Ni Made Dwi Sandhiutami is scientist and lecturer at Faculty of Pharmacy, University of Pancasila, Indonesia. Now She is doctoral student at Biomedical Science, Faculty of Medicine, Universitas Indonesia. Her research is Pharmacology, Biomedical Science and Clinical Pharmacy.

Yesi Desmiaty: Yesi Desmiaty is a doctoral student at the Faculty of Pharmacy, Universitas Indonesia (UI) and is also currently a lecturer at Faculty of of Pharmacy, University of Pancasila, Indonesia. She conducted research on Phytochemical Isolation of Natural Products and Analytical Chemistry.

Noviyanti: Noviyanti was graduated at Faculty of of Pharmacy, University of Pancasila, Indonesia and held the role of assistant lecturer at Pharmacology Laboratory. She is currently pursuing a Pharmacist Profession Program at Univerity of Pancasila, Indonesia.

Cite this article: Sandhiutami NMD, DesmiatyY, Inhibitory Effect of Lantana camara L., Eclipta prostrata (L.) L. and Cosmos caudatus Kunth. Leaf Extracts on ADP-Induced Platelet Aggregation. Pharmacog J. 2018;10(3):581-5. 